\title{
A New Model of Christian Interaction with the Jews
}

\section{Pietist and Evangelical Missions to the Jews}

The turn of the eighteenth century saw the rise of a new movement in the landscape of Western Christianity and Christian-Jewish relations - German Pietism, which provided an alternative means for Protestants to relate to Jews. ${ }^{1}$ The Halle Pietists thus became one of the important movements in the Protestant world, and their pioneering mission, the Institutum Judaicum, influenced other groups of Pietists in Central and Northern Europe, as well as English-speaking evangelicals, making a lasting impression on the Protestant scene, modifying, and at times transforming, prevailing attitudes towards the Jews. An exploration of the agenda of this movement, then, may unveil a rich picture of this highly complicated relationship.

\section{The Roots and Origins of Pietist Attitudes Towards the Jews}

To a certain extent, Pietist attitudes towards the Jews recall those of the early Martin Luther. ${ }^{2}$ Like the father of the Protestant Reformation, the Pietists believed that Jews ought to be open to Christianity in its Protestant form. Pietists,

1 On the rise, nature, and impact of German Pietism, see Peter E. Erb, ed., The Pietists: Selected Writings (New York: Paulist Press, 1983); Jonathan Storm, Hartmut Lehmann, and James Van Horn, eds., Pietism in Germany and North America, 1680-1820 (Aldershot: Ashgate, 2009); Douglas Shantz, An Introduction to German Pietism: Protestant Renewal at the Dawn of Modern Europe (Baltimore: Johns Hopkins University Press, 2013); Douglas Shantz, A Companion to German Pietism, 1680 -1800 (Leiden: Brill, 2014).

2 Luther's complicated and changing attitudes towards the Jews have received considerable scholarly attention. For an updated comprehensive study of the subject, see Thomas Kaufmann, "Luther and the Jews," in Jews, Judaism, and the Reformation in Sixteenth Century Germany, eds. Dean Philip Bell and Stephen G. Burnett (Leiden and Boston: Brill, 2006), 69-104; Peter von der Osten-Sacken, Martin Luther und die Juden: neu untersucht anhand von Anton Margarithas “Der gantz Jüdisch glaub” (1530/31) (Stuttgart: W. Kohlhammer, 2002); Thomas Kaufmann, Luther's Jews: A Journey into Antisemitism (Oxford and New York: Oxford University Press, 2017).

○ OpenAccess. () 2020 Aue-Ben-David et al., published by De Gruyter. (cc)BY This work is licensed under the Creative Commons Attribution 4.0 International. https://doi.org/10.1515/9783110664713-007 
however, carried Luther's theological and practical positions a few steps further. In his early career as a reformer, Luther held hopes for the conversion of the Jews to Christianity, but stopped short of establishing a mission or formulating specific means of approaching them. Pietists institutionalized and systematized the agenda outlined by the young reformer. But, unlike Luther, who was disappointed that the Jews did not join his new Protestant church en masse, Pietists, and later on, evangelical missionaries, accepted that most Jews were not interested in converting to Christianity. Content to convert only a limited number of Jews, Pietists set their sights on those individuals who were thus inclined.

Pietist agendas were strongly shaped by the ideas of Philip Jacob Spener (1635-1705), founder of Halle Pietism. In his Pia Desideria, the most influential work of German Pietism, Spener promoted an alternative attitude towards the Jews. ${ }^{3}$ There, the Pietist thinker expressed appreciation for the longstanding Jewish rejection of Christianity. He blamed Christian societies for mistreating the Jews, and called upon his readers to show good will towards them. Promoting a messianic outlook, Spener, and the Halle Pietists whom he inspired, as well as a number of other Pietist groups that followed them, were convinced that the Jews would again play a decisive role in the events that would lead to the materialization of the Kingdom of God on earth.

Although Pietism developed mostly in Lutheran lands, the Reformed (often labelled 'Calvinist') wing of the Reformation influenced Pietist positions towards the Jews. ${ }^{4}$ Reformers of that school, such as Martin Bucer (1491-1551), John Calvin (1509-1564), and Theodore Beza (1519-1605), took with utter seriousness the messages conveyed in the Hebrew Bible, including the idea that their communities were in covenant with God. ${ }^{5}$ Unlike Luther, who believed that the place of the Jewish people in history, as an entity distinct from Christianity, had come to an end, Calvin held that while God was angry with Jews as individuals, Jews might still be redeemed as a nation. ${ }^{6}$ Reformed thinkers in England,

3 Philip Jacob Spener, Pia Desideria or Heartfelt Desire for a God-Pleasing Reform of the True Evangelical Church, trans. Theodore G. Tappert (Philadelphia: Fortress Press, 1964). The original text appeared in Frankfurt am Main in 1675.

4 Walter Beltz, "Gemeinsame kulturelle Codes in koexistierenden Religionsgemeinschaften, dargestellt und untersucht an Beispielen der Messiasdiskurse in den Reisetagebüchern des Institutum Judaicum et Muhammediacum J. H. Callenbergs,” in Sprache und Geist: Peter Nagel zum 65. Geburtstag, eds. Walter Beltz, Ute Pietruschka, and Jürgen Tubach (Halle: Martin-Luther-Univ. Halle-Wittenberg, 2003): 1-29.

5 Cf. G. Sujin Pak, The Judaizing Calvin: Sixteenth-Century Debates Over the Messianic Psalms (Oxford and New York: Oxford University Press, 2010).

6 John Calvin, Commentary on a Harmony of the Evangelists, Matthew, Mark, Luke, translated from the original Latin by the Rev. William Fringle, volume 3, Christian Classics Ethereal Library 
Holland, France, and Switzerland, as well as in those parts of the New World where Reformed theology gained ground, expressed hope for the Jews' prospect of national restoration and conversion to Christianity. ${ }^{7}$ Pietism found parallels and support in Reformed communities, including the Puritan movement that developed in England and New England. ${ }^{8}$ Many Pietists and Puritans viewed the Jews as heirs of historical Israel, and focused on the prospect of the return of the Jews to the Holy Land and their conversion to Christianity. ${ }^{9}$ Puritans and Pietists adhering to a Christian messianic faith insisted that the biblical references to Israel, Judah, Zion, and Jerusalem should be read literally, and that the old Testament prophecies about the rejuvenation of Israel were meant for the

(Grand Rapids, MI: Baker Books, 2003), here 27:25-26. Calvin starts the commentary along traditional Christian lines, but then moves to promote the idea that God still upholds his promises to Israel and a remnant of the Jews shall be redeemed. http://www.ccel.org/ccel/calvin/cal com33.ii.xxxix.html?scrBook=Matt\&scrCh=27\&scrV=25\#ii.xxxix-p11.1

7 Cf. Myriam Yardeni, Huguenots and Jews (Jerusalem: The Zalman Shazar Center for Jewish History, 1998), 83-112; J. Van den Berg, "Eschatological Expectations concerning the Conversion of the Jews in the Netherlands during the Seventeenth Century," in Puritans, the Millennium and the Future of Israel: Puritan Eschatology, 1600 -1660, ed. Peter Toon (Cambridge: James Clarke, 1970): 137-53, esp. 137-9; Frank E. Manuel, The Broken Staff: Judaism through Christian Eyes (Cambridge, MA: Harvard University Press, 1992), 92-8.

8 Richard F. Lovelace, The American Pietism of Cotton Mather: Origins of American Evangelicalism (Grand Rapids, MI: Christian University Press, 1979), 32-5, 65-6.

9 Franz Kobler, The Vision was There: A History of the British Movement for the Restoration of the Jews to Palestine (London: Lincolns-Prager, 1956); Peter Toon, “The Latter Day Glory," in idem, ed., Puritans, the Millennium and the Future of Israel, 23-41; Carl F. Ehle, "Prolegomena to Christian Zionism in America: The Views of Increase Mather and William E. Blackstone Concerning the Doctrine of the Restoration of Israel” (Ph.D. Diss., New York University, 1977), 47-61; Mel Scult, Millennial Expectations and Jewish Liberties: A Study of the Efforts to Convert the Jews in Britain up to the Mid-Nineteenth Century (Leiden: Brill, 1978); Robert M. Healers "The Jews in Seventeenth Century Protestant Thought," Church History 46:1 (1979): 63-79; David S. Katz, Philo-Semitism and the Readmission of the Jews to England, 1603-1655 (Oxford: Clarendon Press, 1982); Barbara W. Tuchman, Bible and Sword: England and Palestine from the Bronze Age to Balfour (London: Macmillan, 1983), 80-101; Christopher Hill, The English Bible and the Seventeenth Century Revolution (London and New York: Penguin, 1994); Christopher Hill, "Till the Conversion of the Jews," in idem, Religion and Politics in Seventeenth Century England (Brighton, Harvester Press, 1986), 269-300; Mayir Verete, From Palmerstone to Balfour: Collected Essays, ed. Norman A. Rose (London and Portland, OR: Frank Cass, 1992); Avihu Zakai, "The Poetics of History and the Destiny of Israel. The Role of the Jews in English Apocalyptic Thought during the Sixteenth and Seventeenth Centuries," Journal of Jewish Thought and Philosophy 5 (1996): 313-50; Eitan Bar-Yosef, The Holy Land in English Culture 1799-1917: Palestine and the Question of Orientalism (Oxford and New York: Clarendon Press and Oxford University Press, 2005). 
Jews. ${ }^{10}$ With this ideological backdrop, these Christians were keen to seek out Jews for interaction.

Pietists' faith in the imminent return of Jesus to earth rendered their work among Jews pivotal to the unfolding of their notion of the divine plan for salvation. They sought to educate Christians about the messianic role of the Jews and to instruct the latter as to what was, from the Pietist point of view, their true historical mission. In their eyes, Jews were poised to return to the Holy Land to prepare the ground for Jesus' return and the eventual establishment of the Kingdom of God on earth. This theme became a central topos in Pietist literature intended for dissemination among Jews. ${ }^{11}$ Other Protestant missions to the Jews that emerged in the wake of the Halle Pietist mission, such as the London Society for Promoting Christianity among the Jews, adopted or produced similar literature. ${ }^{12}$

\section{The Halle Pietists and the Evangelization of the Jews}

If the Jewish people were tasked with a special mission in God's plans for the messianic times, they merited time and resources: as such, many Pietist groups prioritized their evangelization. Wishing to approach Jews effectively, Pietists equipped their evangelists with knowledge of Jews, Judaism, and Jewish culture. Eighteenth-century German Protestants took an increasing interest in the Jews, their language, culture, and beliefs, as well as their economic and civic status. ${ }^{13}$ Halle offered an excellent infrastructure for training and supporting informed missionaries. Among other opportunities, the university, which Spener and other Pietists had established in that city, offered a range of courses in Jewish languages, including Hebrew, Aramaic, and Yiddish. In time, the University of

10 Toon, "The Latter Day Glory," 26-34.

11 Miktav ahavah el kol asire ha-tiqwah ha-meyuhalim an ale bene goles Yisroel di oyf di geule vartn ihertslikher libshaft geshribn/D. Jo. Mulleri Ecclesiastæ Gothani Ad Judæos plena caritatis epistola. recudi curavit ... Jo. Henr. Callenbergius, Johann Müller (Halle: Institutum Judaicum, 1747).

12 Yaakov S. Ariel, Evangelizing the Chosen People (Chapel Hill: University of North Carolina Press, 2000), 9-21.

13 Yaacov Deutsch, Judaism in Christian Eyes: Ethnographic Descriptions of Jews and Judaism in Early Modern Europe (Oxford and New York: Oxford University Press, 2012); Aya Elyada, A Goy Who Speaks Yiddish: Christians and the Jewish Language in Early Modern Germany (Stanford, CA: Stanford University Press, 2012). 
Halle became an important center of research and teaching on Semitic languages, and Biblical and Near Eastern studies. Moreover, the town possessed printing presses that published books in those languages. Headed by Johann Heinrich Callenberg (1694-1760), the new mission started at the University of Halle, where Callenberg began teaching courses for prospective missionaries in 1724 , four years before the official founding date of the mission. The Pietist leader would hold a dual position as a university instructor and head of the mission. Callenberg was in charge of the production of books that enhanced extensive missionary fieldwork that aimed to reach Jews in Central and Eastern Europe, as well as in other parts of the Jewish world. ${ }^{14}$

The Institute yielded an impressive legacy: the comprehensive study of Jewish traditions, customs, and languages, as well as a proliferation of texts on and for Jews. It helped shape dozens of other missions, including in Britain, Scandinavia, Holland, America, Eastern Europe and Palestine. Many of these missions emulated the Halle-mission tactics and produced similar publications. ${ }^{15}$

The novelty of this approach merits a moment of appreciation. Traditional Christian theology and popular opinion had long perceived the Jews as a people frozen in time, practicing a uniform and static tradition. Little attention had ever been paid to the actual customs of the Jews, including their synagogue rites, home-based rituals, religious paraphernalia, and rites of passage. Interest would arise mostly when rumors spread of Jewish disrespect in texts and prayers towards Christianity. ${ }^{16}$ Likewise, Christians had previously taken scant notice of the diversity of Judaism and the differing ethnic groups and languages of the Jews. In addition to the study of the Jews, their languages and cultures, the Institutum Judaicum took upon itself to carry out itinerant visits and discussions with thousands of Jews in dozens of different locales in Central and Eastern Europe. Institute missionaries would regularly dispatch reports on routine life in the Jewish communities they visited. ${ }^{17}$

14 Christoph Rymatzki, Hallischer Pietismus und Judenmission: Johann Heinrich Callenbergs Institutum Judaicum und dessen Freundeskreis 1728-1736 (Tübingen: Niemeyer, 2004).

15 Christopher Clark, The Politics of Conversion: Missionary Protestantism and the Jews in Prussia, 1728-1941 (Oxford: Clarendon Press, 1995); Albert E. Thompson, A Century of Jewish Missions (Chicago: Fenning H. Revell, 1902).

16 Isak Nethanel Gath, The Sorcerer from Schwabach: The Process of the Chief Rabbi of the -Ansback Principality, Hirsch Fränkel [hebr.] (Tel Aviv: Ha-kibbutz ha-meuchad, 2013).

17 Rymatzki, Hallischer Pietismus und Judenmission; Thomas Müller-Bahlke, "Die Reisetagebücher des Institutum Judaicum et Muhammedicum der Reisen durch Polen 1730/31, Kwartalnik Historii Żydów (Jewish History Quarterly) 4 (2006): 504-8. 
Those representatives of the Institute acted as ethnographers, touring Jewish communities and recording their impressions. ${ }^{18}$ The Halle Pietists' trademark was to enter Jewish spaces, including synagogues, private homes, and markets, and engage in conversations with individuals and groups, soliciting their opinions and eliciting their everyday concerns. ${ }^{19}$ Among other discoveries, Pietists found rampant poverty among Jews, a reality that stood in stark contrast to the prevailing stereotypes about them held by contemporary Christians. The rise of Pietism and the early activity of the Institutum Judaicum took place during the heyday of 'court Jews,' a handful of entrepreneurial Jews who served as aides, advisors and managers to local rulers, including Moses Benjamin Wulff (1661-1729), who acted as the lieutenant of the Duke of Anhalt-Dessau, in whose territory the Halle Pietists operated. The Pietist missionaries soon discovered, however, that the Jewish masses were far removed from court life. In fact, most Jews lived in deprivation in comparison to Christian burghers, with no access to higher education, the professions, the military, or other economic opportunities. ${ }^{20}$

Jewish historians have given somewhat short shrift to protective attitudes evinced by German Protestants, such as Pietist activists, towards Jews. ${ }^{21}$ Pietists have even been portrayed as hostile towards them. ${ }^{22}$ However, while not shying away from criticism of Jews, Pietists defended them against what they considered unfair condemnations, such as blood libels, which were still prevalent in Central and Eastern Europe. Moreover, they advocated improving the civil and economic conditions of the Jews. Pietists and, later, evangelical missionaries, would militate against harassment of Jews all around the world, claiming good will towards the Jews as a Christian virtue, and condemning physical and legal attacks against them.

18 Ibid.

19 Christoph Bochinger, "Die Dialoge zwischen reisenden Studiosi und Juden in religionswissenschaftlicher Perspektive,” Kwartalnik Historii Żydów (Jewish History Quarterly) 4 (2006): $509-20$.

20 On Jews in Central Europe in the Early Modern Era, see Elisheva Carlebach, "The Death of Simon Abeles: Jewish-Christian Tension in 17th Century Prague.” The 3rd annual Herbert Berman memorial lecture, Center for Jewish Studies, Queens College (New York, CUNY, 2001); Dean Philip Bell, Jews in the Early Modern World (Lanham, MD.: Rowman \& Littlefield, 2008). 21 Among the exceptions are Baruch Mevorach, "Messianic Hopes within the Discourse on the Emancipation of Jews and Early Reform” (Ph.D. Diss., Hebrew University of Jerusalem, 1966); Alan T. Levinson, Between Philosemitism and Antisemitism: Defenses of Jews and Judaism in Germany, 1871-1932 (Lincoln and London: University of Nebraska Press, 2004).

22 Gath, Sorcerer from Schwabach. 
While expressing sympathy with Jews and protecting them in the public arena, Pietist methods of evangelism did not share twenty-first century standards of tolerance towards other people's faiths. Moving from one Jewish community to the next, missionaries used aggressive tactics and did not hesitate to make provocative statements. In that manner, itinerant evangelists engaged Jews in debates on the appropriate manner of reading Jewish sacred texts, and discussed with them whether the Messiah had already come once before or not. There was certainly an 'exchange' between Pietists and Jews, but hardly in any contemporary sense of interfaith dialogue.

Pietist missionaries also did not always present themselves as what they were. The diaries of two studiosi, the itinerant missionaries Georg Widmann (1693-1753) and Johann Andreas Manitius (1707-1758), reveal that, relying on their remarkable knowledge of Jewish languages, culture, and teachings, sometimes the missionaries were able to conceal their Christian identities. ${ }^{23}$ In the Widmann and Manitius cases, the Jews suspected that the visitors might not have been Jewish, but were nevertheless curious and therefore gave them the benefit of the doubt. Some wanted to learn more about the Pietist movement, and a number of young Jews contemplated conversion.

Pietist evangelists, as well as evangelical missionaries who came on the scene in the Anglo-Saxon world of the nineteenth century, were certain that their versions of Protestantism would be palatable to the Jews. It was, they believed, a purist, fully reformed Protestantism, which Jews should be able to relate to more easily than other forms of Christianity. By the eighteenth century, the Protestant Old Testament had come to resemble the Jewish Tanakh. Protestants mostly printed their bibles without the Apocrypha, those parts of the Roman Old Testament that the Jews had not canonized, such as the books of Judith and the Maccabees. ${ }^{24}$ This process, in which the Pietists played a crucial role, would prove vital to the messages of the Pietist missions. When approaching Jews, Pietist missionaries and their successors pointed to chapters and verses in the Hebrew Bible as a basis for theological discussions. Pietists and, later, evangelicals who engaged in missionizing Jews, presented their church environments, liturgies, and ministry as non-offensive to Jewish sensibilities, suiting Jewish styles and concepts. Their houses of worship were empty of iconography; they did

23 Bochinger, "Dialoge," 514-8.

24 Luther removed a number of texts from the canon and placed them under the rubric of Apocrypha, included in the Bible, but not carrying a canonical status. 
not perform the rite of the Eucharist, and their ministers, conducting services without vestments and preaching about biblical passages, were not priests. ${ }^{25}$

While sharing a similar corpus of sacred scriptures with the Jews, Pietist missionaries were certain that theirs was the correct manner of reading the Bible. For Pietists, their version of the Christian faith, which emphasized regeneration, would lead to salvation and eternal life, while Judaism lacked the ability to offer spiritual guidelines and eternal salvation. Despite their ardent desire to interact with Jews, from the Pietists' point of view, such meetings took place between non-equals. ${ }^{26}$ They alone possessed the correct understanding of God's plans for human history, and it was their mission to share it with Jews. While Pietists, like many Puritans and Reformed thinkers, and later on evangelical ones, developed hopes for the revival of the Jews in a restored Davidic kingdom, they agreed with the traditional Christian understanding that observance of the commandments was purposeless after the sacrifice of Jesus on the cross. Only faith in Jesus could redeem the Jews. ${ }^{27}$

Rather expectedly, Jews did not always welcome encounters with Pietist studiosi. Jewish leaders experienced Pietist overtures as intrusive, a violation of their integrity as people upholding their ancestral faith. ${ }^{28}$ Often, however, the missionaries could rely on individual Jews - particularly young ones - to lend an ear. In their distance from majority-Christian groups, Pietists had greater emotional access to Jews than their more established Christian brethren. Most Jews lived at that time among Catholic, Uniate, or Orthodox Christians, with the patterns of immigration giving growing preference to Protestant lands, where previously Jews had been forbidden to settle. Jews often related to Christian authorities as alien, but some of them felt that the Pietists were different, friendlier and more well-meaning.

While Jewish leaders considered missionaries a threat, they could not always grasp the ideas that motivated the Pietists and evangelicals to take an interest in

25 Promotion of Protestantism as embodying the purity and authenticity of both Judaism and Christianity appear in a number of the Institute's publications; See [Institutum Judaicum et Mohammedaicum], Catalogus 1748, was zum Gebrauch der Juden [Muhammedaner ... alten orientalischen Christenheit ... Abendländer ... Abendländischen Christen] herausgegeben (Halle: Institutum Judaicum, 1748).

26 Bochinger, "Dialoge," 509-20.

27 Preferring to emphasize certain elements of the Pietist views and activities, David Dowdey claims that Pietists such as Callenberg re-humanized the Jews; see David Dowdey, Jewish-Christian Relations in Eighteenth-Century Germany: Textual Studies on German Archival Holdings, 1729-1742 (Lewiston, NY.: Edwin Mellen Press, 2006), especially introduction and chapters IV and $\mathrm{V}$.

28 Ariel, Evangelizing the Chosen People, 55-68. 
the Jews. Jewish activists would approach Pietist or evangelical missionaries, such as Franz Delitzsch (1813-1890), who considered the mission he established in Leipzig to be a continuation of the Institutum Judaicum; or William Blackstone (1840-1935), founder of the Chicago Hebrew Mission, asking for their help in combating anti-Jewish accusations or, later on, promoting Zionist activities. Both Delitzsch and Blackstone militated, in books and articles, against the Blood Libel and other forms of discrimination or harassment of Jews. ${ }^{29}$ Delitzsch cooperated with Jewish scholars, such as Moritz Steinschneider (1813-1897), on literary projects, while Blackstone worked in tandem with Zionist leaders, such as Stephen Wise (1874-1949). ${ }^{30}$

While promoting the idea of the Jews' centrality in God's plans and developing protective attitudes towards them, Pietists often held stereotypical images of Jews as a people. Contemporary historians who have examined Pietist and early evangelical views of Jews have sometimes been taken aback by these beliefs. ${ }^{31}$ Yet such sentiments ought to be analyzed within the context of their time and place, which often held opinions of Jews that had been percolating in European societies for centuries. Considering the Jews as God's first - albeit temporarily cast-aside - nation, Pietists related to the Jews with more goodwill than many other Christians of the period. ${ }^{32}$ Concurrent with the Halle Pietists' activities, some non-Pietist German writers, such as Johann Andreas Eisenmenger (16541704), wrote very different tracts, conveying outright hostility towards the Jews. ${ }^{33}$ Naturally, one finds variation in Pietist attitudes towards Jews. Wuerttemberg Pietists related to them in a different way than Halle Pietists did. Some Wuerttemberg Pietists were not eschatologically oriented and did not envision a special role for the Jews in history. Still, for the most part, Pietist missionaries held to eschatological hopes and considered the Jews a special people, even if

29 See, for example, Franz Delitzsch's contribution in Christliche Zeugnisse gegen die Blutbeschuldigung der Juden, ed. Alois Müller (Berlin: Walther \& Apolant, 1882): 12-8; on Franz Delitzsch's publications in support of Jews and their culture, see Franz Curtiss, Franz Delitzsch: A Memorial Tribute (Edinburgh: T\&T Clark, 1891), 70-80; on Blackstone, see Yaakov S. Ariel, On Behalf of: American Attitudes Towards the Jewish People, Judaism and Zionism (Brooklyn, NY: Carlson, 1991), 55-96.

30 For example, Franz Delitzsch and Moritz Steinschneider, Ez Hayyim (Leipzig: J. A. Barth, 1841).

31 Giuseppe Veltri, "Die Diarii des Callenberg-Instituts: Eine Quelle zur Jüdischen Kulturgeschichte in der ersten Hälfte des 18. Jahrhunderts,” in Kwartalnik Historii Żydów (Jewish History Quarterly) 4 (2006): 652-61.

32 Peter Vogt, ed., Zwischen Bekehrungseifer und Philosemitismus: Texte zur Stellung des Pietismus zum Judentum (Leipzig: Evangelische Verlagsanstalt, 2007).

33 Cf. Dowdey, Jewish-Christian Relations in Eighteenth-Century Germany, chapters IV and V. 
they did not always express positive views about Jewish ways. Although communicated in very different political, cultural, and ecclesiastical settings, the attitudes of nineteenth-century English-speaking evangelical missionaries resembled those of eighteenth-century Pietists, a resemblance that was evident in their literature. ${ }^{34}$

\section{Literature for and about Jews}

The Pietist mission produced books for Jews as prospective converts. Likewise, the missionaries disseminated literature intended to increase knowledge of Judaism and Jews among Christian audiences and interested laypersons. ${ }^{35}$ The leaders of the Institutum Judaicum wished to present Jewish life, culture, and languages in a manner that would stir up sympathy and support. Pietist missions in continental Europe and evangelical missions would adopt, adapt, and increase the volume of publications and readers of such tracks. ${ }^{36}$ These books and instruction manuals pointed to an acute interest on the part of Pietists in the Jews and their culture, and a wish to engage with and influence them. ${ }^{37}$ The publications also allowed missionaries to give expression to their literary ambitions, including in the realms of translation and editing, demonstrating their knowledge of Jewish languages and texts. ${ }^{38}$

In the eighteenth century, Yiddish (or rather Western Yiddish, as it is called today) was still the language of the German Jews, and hence a powerful tool in the missionary endeavors of the German Pietists. ${ }^{39}$ The Institute's publications included a manual for the study of Yiddish (1733) and a Yiddish-German lexicon (1736). ${ }^{40}$ Christians had written similar manuals before, mostly to assist mer-

34 Yaakov S. Ariel, An Unusual Relationship: Evangelical Christians and Jews (New York: New York University Press, 2013).

35 [Johann Heinrich Callenberg,] Catalogus 1739. Was zum Gebrauch der Juden [...] Muhammedaner [...] Christen] herausgegeben Halle, gedruckt in der Buchdruckerey des jüdischen Instituti, den 8. October. 1739 (Halle: Institutum Judaicum, 1739). The titles of the Institute's publications appear in different languages.

36 For example, Christopher Clark, The Politics of Conversion; Albert E. Thompson, A Century of Jewish Missions.

37 Manuel, The Broken Staff, 249-92; Deutsch, Judaism in Christian Eyes.

38 Elyada, A Goy Who Speaks Yiddish.

39 Ibid., Ch. 1: "Yiddish in the Judenmission."

40 A facsimile of both texts is included in Hans Peter Althaus, ed., Schriften zur jiddischen Sprache [von] Johann Heinrich Callenberg [und] Wilhelm Christian Just Chrysander. Faksimiledruck nach den Ausgaben von 1733, 1736 und 1750 (Marburg: Elwert, 1966). 
chants who wished to trade with Jews. This, however, was the first time such a publication had been designed to convert Jews, ${ }^{41}$ and was the precursor of several Protestant manuals, mostly Pietist and evangelical, promoting knowledge of Jewish languages and cultures. Remarkably, the University of Halle, established in 1698, was the first to offer courses on Yiddish in its curriculum. By the same token, evangelical institutions would become the first schools in the Englishspeaking world to teach Yiddish. Secular or liberal institutions of higher learning, including Jewish schools, would introduce Yiddish to their curricula only in the later decades of the twentieth century. ${ }^{42}$

The Institute published a diverse selection of books in Western Yiddish, ranging from translations of books from the Bible and the New Testament to polemical tracts and Christian catechisms. ${ }^{43}$ Many of the writings intended for the Jews were on prophetic themes. Pietists, and evangelical missionaries who followed in their footsteps, considered the messianic hope to be a meeting point between Pietist convictions and Jewish yearnings for the realization of the messianic times. From this common ground, Pietists set out to convince Jews that the Messiah had already come once before and was about to return. ${ }^{44}$ Pietists, and in the nineteenth century evangelical missions, thus tried to bring Jews to accept the truth of the Gospel by utilizing Old Testament texts, which Jews knew and respected, and which pointed, so Protestants believed, to the appearance and ministry of Jesus. ${ }^{45}$

Pietists peppered their arguments with rabbinical idioms in order to heighten their credibility in Jewish eyes. At the same time, they repudiated the Talmud as an unacceptable authority. In this respect, Pietists followed the traditional, mainline, Christian understanding of the Jewish Oral Law. They considered Jews to be in need of Christianity for their self-fulfillment as human beings and as Jews, and saw Jews who adopted Pietist Protestant Christianity as true Christians as well as 'fulfilled' Jews, a theme that later Pietist and evangelical missionaries and con-

41 With one sixteenth-century exception: Elias Schadäus (c. 1541-1593), was also the first to explicitly promote the usage of Yiddish as part of a 'friendly' missionary approach. See his Mysterium, Das ist Geheimnis S. Pauli Röm. am II. Von bekehrung der Juden (Straßburg: s.n., 1592), esp. in the introduction. On early modern Yiddish manuals intended for Christian merchants and businessmen, see Elyada, A Goy Who Speaks Yiddish, Ch. 5.

42 Ariel, Evangelizing the Chosen People, 93-100.

43 On the missionary translations of biblical texts into Yiddish, see Aya Elyada's article in the present volume.

44 Miktav ahavah el kol asire ha-tiqwah ha-meyuhalim an ale bene goles Yisroel di oyf di geule vartn ihertslikher libshaft geshribn.

45 Arno C. Gaebelein, The Prophet Daniel (New York: London and New York: Marshall Bros, 1905). 
verts would further pursue. They were willing to utilize rabbinical wisdom to achieve that goal. At least on some level, they treated the office of the rabbinate and those holding the title with respect. They quoted rabbis when doing so suited their line of thought, and took pride in rabbis who converted to Christianity, highlighting their rabbinical credentials. At times, the missions promoted views that corresponded to the ideas of Jewish thinkers of their time. In his work on the mission's writings, including those of Halle convert Immanuel Frommann, Elliot Wolfson has alerted us to similarities between these and the writings of eighteenth-century Sabbateans. The towering Jewish rabbinical figure, Jonathan Eibeschütz (16901764), for example, suggested a loosening of the boundaries between Christianity and Judaism in his Ve-avo Hayom El-haAyin. ${ }^{46}$

\section{From the Institutum Judaicum to Evangelicals}

The Institutum Judaicum inspired Pietists in other German locales. ${ }^{47}$ Societies in Switzerland, Holland, Denmark, Sweden, and Norway followed suite, creating their own missionary organizations, which adopted similar theologies, texts, and modes of operation. ${ }^{48}$ While the Halle Pietists directed much of their attention to the Jewish populations in Central and Eastern Europe, younger Pietist and evangelical missions in the nineteenth century carried out many of their operations in Western Europe and North America. If previously there were not large communities of Jews in those areas, matters now began to change. The rise of new missions in the New World paralleled patterns of Jewish migration. Pietist, and later evangelical missions, targeted these cohorts.

Pietism had a notable effect on the evangelical missions that sprung up in English-speaking countries at the beginning of the nineteenth century. Like Pietists, evangelical Christians have emphasized the centrality of the Christian sacred scriptures, both the Old and New Testaments, and propagated a more literal reading of the Bible. And, similar to Pietists, many evangelical Christians adhere to a messianic faith, which has often assumed the restoration of Israel to its ancestral land. ${ }^{49}$ Finally, similar to Pietists, evangelicals found mission an effec-

46 Elliot R. Wolfson, "Immanuel Frommann's Commentary on Luke and the Christianizing of Kabbalah: Some Sabbatean and Ḥasidic Affinities,” in Holy Dissent: Jewish and Christian Mystics in Eastern Europe, ed. Glenn Dynner (Detroit: Wayne State University Press, 2011): 171-222. 47 On the mission in Berlin, see Clark, The Politics of Conversion.

48 Thompson, A Century of Jewish Missions.

49 Timothy P. Weber, Living in the Shadow of the Second Coming: American Premillenialism, 1875-1982 (Chicago and London: University of Chicago Press, 1988). 
tive avenue of approach to the Jews. ${ }^{50}$ Evangelical missions further systematized and globalized the existing Pietist missionary networks. Evangelical groups that came after the Pietists built store-front missionary centers, which included reading rooms and book stores. Much of their literature was in Yiddish, the native language of most Jews, both in Eastern Europe and among immigrants to the New World, and in addition to books, they printed journals and distributed flyers. Missions recruited Yiddish-speaking evangelists, and at times included the teaching of Yiddish in training courses. In that, too, they followed the Institute's example, attempting to reach Jews in their own languages, and utilizing Jewish texts, hopes, and imagery. ${ }^{51}$

As impressive as the Halle Pietist literary ventures were, evangelical missionaries would challenge them, seeing a need to replace early Pietist literature. While the Halle translations were more than adequate in the eighteenth century, evangelical missionaries in the nineteenth century, and even more so in the twentieth, found them unsatisfactory. ${ }^{52}$ By the time evangelicals were preparing tracts and copies of the sacred scriptures for the Yiddish-reading audience, the Yiddish that the Institutum Judaicum labored with, namely Western Yiddish, was in rapid decline. In the early nineteenth century, German, Dutch, Alsatian, and Swiss Jews abandoned their Yiddish in favor of High German, or Dutch, or French. Eastern Yiddish thrived among East European Jews who, by the end of the nineteenth century, established new, often secular, venues of creativity in that language. These creative outlets included journals and belles-lettres, political and ideological tracts, as well as a lively theatrical scene. With Eastern European Yiddish alive and well, the gap between it and the by-now defunct Yiddish of eighteenth-century Central and Western European Jews grew even greater. Despite the exquisite quality of the eighteenth-century translations and the knowledge of Jewish texts that they conveyed, they seemed archaic to later generations of Yiddish-reading missionaries and potential converts, who felt that disseminating these early missionary tracts was counterproductive. ${ }^{53}$ So, while the literary

50 Ernest R. Sandeen, The Roots of Fundamentalism: British and American Millenarianism, 1800-1930 (Chicago and London: University of Chicago Press, 1970), 36-9, 53-60, 62-4; Weber, Living in the Shadow, 9-10.

51 On the program at the Moody Bible Institute, see Ariel, Evangelizing the Chosen People, 93100.

52 Henry Einspruch, "Literature for the Christian Approach to the Jews," in Christians and Jews: Report of the Atlantic City Conference on the Christian Approach to the Jews, ed. John S. Conning (New York: s.n. 1931): 97-102.

53 Einspruch, "Literature for the Christian Approach to the Jews"; Ariel, An Unusual Relationship, $126-41$. 
initiatives of the Institutum Judaicum served as a model for dozens of missions that came after it, its actual publications were later cast aside. It is perhaps symbolic of the shifting map of Pietist and evangelical missionary hubs that the most comprehensive collection of materials from the Institutum Judaicum is currently housed in the Library of Congress in Washington, DC. ${ }^{44}$

\section{Conclusion}

Pietists represented a new development in the realm of Protestant interactions with the Jews. While some Pietist opinions on Judaism and Jews followed older Christian paradigms, the attitudes as a whole were innovative, if not revolutionary. Proposing a non-supercessionist understanding of the Jews and their role in history, Pietists have mostly perceived the Jews as a people carrying a special mission. They were willing to invest heavily in sharing with Jews the Pietist reading of the scriptures and messianic vision for the End-Times - regardless of the number of converts they could recruit. While they considered their version of Christianity to be superior to the Jewish faith, they were also protective of Jews and argued for improvement in the Christian treatment of Jewish minorities. Pietists, and many evangelicals whom they influenced by their example, encouraged borderline Christian-Jewish expressions, resulting in individuals, communities and literatures that bridge the two faiths.

Evangelicals have expanded various ideas and attitudes that made their debut with the Pietists. Frommann's vision of blurring the boundaries between Christianity and Judaism found heirs in evangelical writers and leaders such as Arno Gaebelein (1861-1945) and Ernest Ströter (1846-1922), Germans who labored in Germany and the United States in the late nineteenth century. By the turn of the twentieth century, attempts at creating borderline bodies of faith and culture that transformed older divisions between Judaism and Christianity had become more normative among evangelicals, resulting in hybrid communities that sought to combine the two traditions. A new, postmodern spirit of inclusivity and choice allowed for the rise of Hebrew Christians, Messianic Jews, and Jewish Believers in Jesus, groups that attempt to meld Jewish identity and rites with Christian evangelical tenets of faith. This phenomenon traces its roots directly to the theology, agenda, and literature of Pietists and evangelicals.

54 Naomi Seidman, “A Gift for the Jewish People: Henry Einspruch’s Der Bris Khadoshe, Poetics Today 35 (2014): 303-23. 